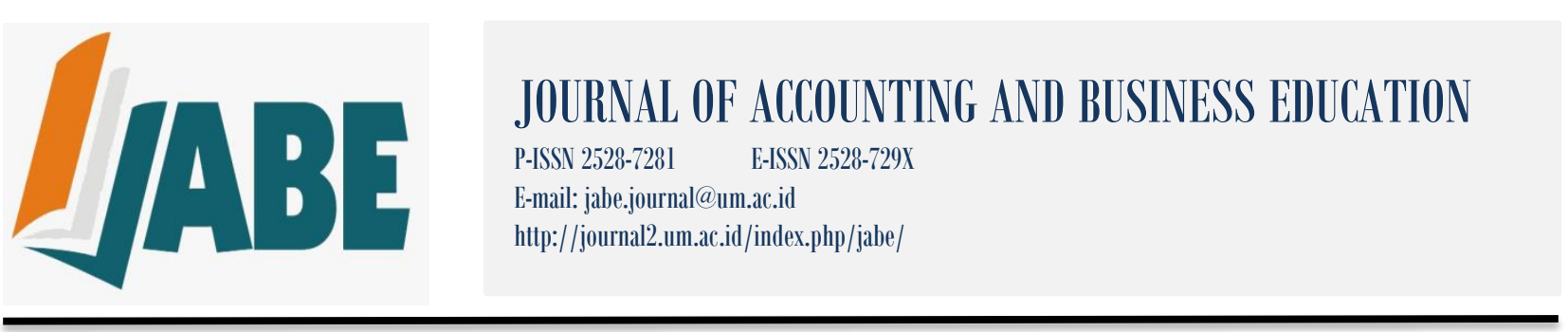

\title{
Does Auditor Independence Mediate the Relationship Between Auditor Rotation and Audit Quality?
}

\author{
Lutfi Ardhani ${ }^{1}$ \\ Bambang Subroto ${ }^{2}$ \\ Bambang Hariadi ${ }^{3}$ \\ ${ }^{1}$ Accounting Department, Faculty of Economic, UIN Maulana Malik Ibrahim Malang, Indonesia \\ ${ }^{2,3}$ Accounting Department, Faculty of Economic, Universitas Brawijaya, Indonesia \\ email:lutfi.ardhani@uin-malang.ac.id
}

DOI: http://dx.doi.org/10.26675/jabe.v4i1.8145

\begin{abstract}
This research was conducted based on issues related to the decline in public trust in the ability of auditors to produce quality audits. This study aims to provide empirical evidence about audit quality that is influenced by auditor rotation. This research aims at providing an empirical evidence of the influence of auditor rotation on audit quality. This is an explanatory study using 90 auditors in Indonesia as its sample. The sample is taken using random sampling and the data are collected using questionnaire and interview with several auditors. The research results indicate that auditor rotation is not found to have direct influence on audit quality. The research also fails to provide empirical evidences of the role of auditor's independence auditor as an intervening variable. Nevertheless, the research does proves that auditor's independence has positive influence on audit quality.
\end{abstract}

Keywords: auditor rotation, auditor's independence, audit quality

\section{INTRODUCTION}

The audit cases occuring around 2000s were mostly related to audit quality issues. This was what led to the modification of auditing standards to improve audit quality and at the same time regain the public trust on both the auditor and public accountant professions. However, this standard modification neither immediately prevented all violations from occuring nor improved the audit quality at once. The violation cases related to audit quality and involving auditors kept on occuring in Indonesia. An example of the recent case occuring in Indonesia was the audit of PT Sunprima Nusantara Pembiayaan's (SNP Finance) financial statements for 2012 to 2016 fiscal years which involved the public accountant Marlinna, Public Accountant Merliyana Syamsul, and Public Accountant Office (KAP) Satrio Bing, Eny \& Rekan (Deloitte Indonesia). In this case, the public accountants Marlinna and Merliyana Syamsul had not completely complied with the Audit Standards-Public Accountant Professional Standards in performing the general audit of SNP Finance's financial statements. Meanwhile, KAP Satrio Bing Eny \& Rekan had neither well-defined policies nor procedures in the KAP quality control system related to the threat of closeness of senior members of partnership team.

In addition to those case, a case had just been releaded by PCAOB (Public Company Accounting Oversight Board) on 9 February 2017 which involved the Public Accountant Office of Ernst \& Young (EY) partner in Indonesia, namely KAP Purwanto, Sungkoro \& Surja with a telecommunication company 
for the result of financial statements audit of a year ending on 31 December 2011 which was not equipped with adequate evidences. For this case, KAP EY partner was sentenced to pay a fine at US\$ 1 million (around Rp 13.3 billions) to US regulator. As a result of these continuously occuring violations, users of financial statements (investors, creditors, and others) began to re-question the existence of public accountant as an independent party in assessing the reasonability of financial statements issuing a highquality audit report (Purnamasari, 2006).

These scandals encouraged regulators (standards board) to find a way of minimizing the fraud and improving the quality of audit produced and thus the new standards known as ISA (International Standards on Auditing) were applied. ISA was adopted and implemented by Indonesia per 1 January 2013 and it was epected to improve the auditor's performance and eventually resulted in improved audit quality. One of KPMG partner stated that ISA aimed at building understandable, well-defined standards which could be applied consistently to give higher ensurance in relation to the practice uniformity throughout the world. Tuanakotta (2014) suggested that the reason why Indonesia adopted ISA could be seen from the market power and value added to be obtained for doing so. Several major KAPs had prepared themselves or even had implemented ISA before IAPI eventually adopted ISA. These KAPs generally had a global network, thus they were demanded to serve their global and international clients who had adopted the standards issued by the International Federation of Accountants (IFAC). ISA was also expected to improve the audit quality to allow existing and potential investors to have better financial statements. ISA depicted transparent and high-quality auditing standard acceptable throughout the world (Lindberg \& Seifert, 2011).

Previous studies used different measurement to assess audit quality since no accurate measurement was available yet in relation to audit quality. Several researchers defined audit quality based on DeAngelo (1981) who explained that audit quality served as a probability for an auditor to find and report violations in the client's accounting system. Meanwhile, according to Watkins, Hillison, \& Morecroft (2004), audit could be said to have high quality if the auditor could give ensurance that there was neither material misstatements (no material misstatements) nor fraud in the financial statements audit. Furthermore, the International Auditing and Assurance Standards Board (IAASB) built a framework for audit quality which consisted of such elements as input, process, output and key interaction within the financial reporting supply chain and contextual factors. This measurement was also used by Robert Knechel, Krishnan, Pevzner, Shefchik, \& Velury (2013) who classified audit quality indicators into four, namely input, process, outcome and context. This research will use input, process and output to assess the audit quality in reference to IAASB. Input is the competence/expertise an auditor should have such as education, knowledge and experience. Meanwhile, process is an auditor's activities when performing the audit. Finally, output is the judgment issued by an auditor as the audit process comes to an end.

Audit quality is influenced by external and internal factors with the internal ones being from the auditor. One of the external factors allegedly influencing audit quality is auditor rotation. Chi, (2011) found that the auditor rotation used to mitigate the impact of audit tenure could improve audit quality. Meanwhile, an auditor's independence is classified as an internal factor which can influence audit quality Auditor rotation is suspected to influence audit quality with auditor's independence serving as an intervening variable. Research result indicated that the low independence of auditors in Egypt made auditor rotation compulsory to be done in order to improve independence and eventually the audit quality (Mohamed \& Habib, 2013). The auditor rotation obligation in Indonesia is governed in Law No. 5 Year 2011 article 4 paragraphs 1 and 2 which state that the provision of audit service by public accountants and/or KAP to a client's historical financial information for some fiscal years in a row can be limited within a certain period of time. On 6 April 2015, the government had issued the Government Regulation (PP) No. 20 Year 2015 concerning Public Accountant Practice (PP 20/2015) which constituted a further arrangement of Law No. 5 Year 2011 concerning Public Accountant Article 11 paragraph (1) which explained that the provision of audit service to historical financial information as referred to in Article 10 paragraph (1) point a of an entity by a public accountant was limited not longer than 5 (five) consecutive fiscal years. 
Independence has always been an interesting topic since many studies have proven that currently an auditor's independence is subjected to questions due to the large number of cases which involved auditors. This is possible due to the "special relationships/closeness" between clients and the auditors who have alliance for a very long time, resulting in the auditor's decreasing objectivity and independence to the client. To mitigate this closeness between auditors and clients, PP 20/2015 Article 11 paragraph (1) required auditors to rotate in which an auditor was not allowed to audit for the same client for 5 consecutive years. This is to maintain an auditor's independence to allow high quality audit. The tighter the compulsory rotation is done by KAP for its auditor, the higher the independence of an auditor and the higher the audit quality (Copley \& Doucet, 1993).

The result of research conducted by Dattin (2017) in France showed that the mandatory auditor rotation could improve auditor's independence, yet it did not significantly influence the audit quality. This is because of the difficulty in evaluating the effectiveness of system in France in improving the audit quality due to the limited number of studies on that matter. This research finding contradicted Tobi, Osasrere, \& Emmanue (2016) who successfully proved that audit quality could be improved by rotating auditors and Daniels \& Booker (2011) who also succeeded in finding that auditor rotation could influenced auditor's perceived independence and audit quality. However, Onwuchekwa, Erah, \& Izedonmi (2012) found an empirical fact that auditor rotation had negative effect on audit quality. These studies with varied empirical evidences give other researchers a chance to develop a model and re-test the correlation between auditor rotation, auditor's independence and audit quality. Moreover, Patrick, Zayol, Kukeng Vitalis (2017) reviewed some literatures related to the relationship between independence and audit quality. Their review results revealed that auditor's independence is one of the important determinants which influenced audit quality.

This confirms the theory of attribution which suggests that the behavior of a person (in this research an auditor) is influenced, among other things, by external factors, in this case auditor rotation. An auditor is more likely to perform better when external pressure in the form of rotation-related regulation is present. This research is a development of previous studies which failed to prove the accurate and clear-cut correlation between auditor rotation, auditor's independence and audit quality. In this research, auditor's independence is treated as an intervening variable which mediates the correlation between auditor rotation and audit quality, rather than an independent variable with direct influence on audit quality. Based on the explanation and studies mentioned above, the researcher makes a justification which later needs to be proven and re-tested that audit quality is influenced by auditor's independence in performing financial statements audit and the auditor's independence will also improves if KAP performs the compulsory rotation to their auditors to produce high-quality audit reports.

\section{LITERATURE REVIEW AND HYPOTHESES}

\section{Agency Theory}

Watkins et al., (2004) suggested there were four drivers which could influence audit quality. Two drivers were from the demand side and two other drivers came from the supply side. The drivers from the demand side were client's risk strategy and agency conflict. Meanwhile, the drivers from supply side were the auditor risk management strategy and audit fee. From Watkins et al., (2004) opinion above, it can be seen that agency conflict can also play a role of a driver of audit quality. In agency theory, it is suggested that the function of auditing is a mechanism to mitigate agency conflict between managers who act as the agent and the company owners as the principal. Both parties need an auditor to minimize information asymetry between the owners and the managers. The bigger the agency conflict is, the higher the agency cost, and the higher the demand for quality auditor would be.

An important note of the analysis performed by Watkins et al. (2004) is that the agency conflicts are varied between companies and from time to time. The agency conflict occuring in a company whose owners and managers are not separated or relatively not separated is different from the agency conflict occuring in a company whose managers and owners are separated. Therefore, the influence of agency 
conflict on audit quality or demand for audit quality will also be varied in each company. The agency theory proposed by Jensen \& Meckling (1976) explains the agency relationship between the principal as the owner or shareholders and the manager who acts as an agent. Managers are contracted by the principal to work for the principal's interest and to report to the principal. If the agent and the principal work and share the same goals, i.e. to maximize the company's value, it can be said that the agent acts in favor of the principal's interest. Watts \& Zimmerman (1990) argued that the financial statements made in accounting numbers were expected to minimize the conflict among the parties in interests. Using the financial statements reported by the agent as a form of their performance accountability, the principal can assess, measure and monitor to what extent the agent has acted and worked to improve the principal welfare and as the basis for providing compensation or bonus to the agent.

In company where owner as the principal and the manager as an agent who runs the company are separated (not a company managed by the owner themselves) agency problems are frequently occuring since it is assumed that each of the parties tries to maximize their utility functions. The principal and the agent are assumed to constantly act rationally based on their respective economic interests. This wish to maximize their respective economic benefits will cause a clash of interests between them (conflict of interest). The principal is assumed to always want to maximize the organization goal achievement such as company profit and willing to take the risk or at least risk neutral. Meanwhile, the agent is assumed to always put his/her interests to obtain compensation/bonus and avoid risk (risk averse) first. In the principal point of view, the compensation given to the agent is based on the result, yet in the agent's perspective, the compensation system should not consider merely the result, rather the effort made should also be taken into account. The problem in this relationship is known as asymmetry information, where the agent is in possession of more information on the company than the principal, making the principal unable to determine whether or not the efforts made by the agent had been actually optimal.

These agency problems lead to the principal's need for an independent third party (in this case an auditor) who will assess the reasonability of financial statements made in the form of accounting numbers prepared by the agent in order to minimize the potential conflict between the parties in interest. The appointed auditor is required to have independence to allow him/her to bridge the interests from both the principal and the agent. This way the principal would know the actual condition of their company and assess the agent's performance and the agent would receive the compensation/bonus based on his/her performance. The existence of this independent auditor in the relationship between the principal and the agent is also intended to facilitate the creditor and government's interest at the same time. From the audited financial statements, the creditor can see the feasibility of the company to receive loans and the government can see the implementation of its policies (such as taxation) in the relevant company.

\section{Atribution Theory}

Attribution theory studies the process of how an individual interpret an event, reason or cause of their behavior. This behavior was developed by Heider (1958) who argued that one's behavior was determined the combination of two factors, i.e. internal and external factors. The term internal factors meant the factors from within oneself such as ability or effort and the external factor meant those from beyond oneself. Based on this theory, an individual will be motivated to understand their surrounding environment. For example, an employee can be a disciplined worker since discipline has been their characteristics or maybe because of other factors beyond them, they are disciplined since the circumstance requires so, such as when the are afraid of being fired or prevented from being promoted by the company if they are disciplined. If we see/conclude that this individual does something due his/her personality (disciplined), then we have made an internal attribution. Yet, if we see or conclude that what this individual does is due to the pressure of a certain circumstance (afraid of being fired or prevented from being promoted) then we have done an external attribution. In research on behavior, this theory is applied using internal locus of control and external locus of control. In this research, the attribution theory is used to explain how internal and external factors influence an auditor's behavior. The internal factors in this research's context is auditor's independence and the auditor rotation is the external factor which may 
influence the auditor's behavior; these factors will influence the quality of audit produced by the auditor (Lubis, 2010).

\section{Influence of Auditor Rotation on Auditor's Independence}

Auditor rotation is auditor interchange to audit a company. Auditor rotation can be voluntary or mandatory. The voluntary auditor rotation happens if a company (client) voluntarily changes its auditor themselves and the mandatory auditor rotation occurs if it is required by rules. In Indonesia, auditor rotation is mandatory under the Law No. 5 Year 2011 and PP 20/2015 which state that public accountants are allowed to audit a client only for 5 consecutive fiscal years.

The issue of audit rotation has been an interesting topic since auditor rotation is tightly related to independence. Auditor rotation is claimed as one of ways to improve independence since being limited to audit a client thus this auditor's independence can be maintained. Research on auditor rotation conducted by Chi (2011) found that the auditor rotation used to mitigate the impact of audit tenure could improve audit quality. This indicates that auditor rotation can reduce their closeness to and familiarity with the client which are suspected to decrease their professionalism scepticism and independence. Meanwhile, Coyle (2010) who studied 20 KAPs and interviewed the regulators found that audit rotation is a way of improving auditor's independence. Mohamed \& Habib ( 2013) also showed that the low independence of auditors in Egypt made the auditor rotation mandatory in order to improve their independence and eventually the audit quality.

Based on the explanation above, it can be concluded that an auditor's independence will be maintained if the company rotate their auditors. This is in line with the attribution theory which suggests that one's behavior is affected by two factors, namely internal and external factors. Auditor rotation is one of external factors which influences an auditor's independence. As suggested by Coyle (2010), audit report is the final result of audit process. Based on this explanation, it is therefore hypothesized as follows:

\section{$\mathrm{H}_{1}$ : Auditor rotation positively influences auditor's independence}

\section{Influence of auditor's independence on audit quality}

The auditor profession is tightly related to independent attitude. Independence is an objective, impartial and unbiased attitude. Independence in minds is an old requirement that a member should be independent in fact. Meanwhile, independence in appearance is the interpretation of independence in fact. If an auditor in independent in fact yet the user believes that when an auditor becomes an advisor for the client, most of the values of audit function have vanished.

From the agency theory perspective, the auditor profession plays a highly important role to minimize agency conflict between the principal and the agent. The agency theory proposed by Jensen \& Meckling (1976) explains the agency relationship between the principal as the owner or shareholders and the manager who acts as an agent. Managers are contracted by the principal to work for the principal's interest and to report to the principal. If the agent and the principal work and share the same goals, i.e. to maximize the company's value, it can be said that the agent acts in favor of the principal's interest.

However, in fact agents not necessarily act for the principal's interests. Agents are assumed to keep on trying to maximize their own interests hence an agency conflict occurs. These agency problems lead to the principal's need for an independent third party (in this case an auditor) who will assess the reasonability of financial statements made in the form of accounting numbers prepared by the agent in order to minimize the potential conflict between the parties in interest. The appointed auditor is required to have independence to allow him/her to bridge the interests from both the principal and the agent.

It is suspected that independence influences audit quality. The higher the independence of an auditor, the higher the quality of audit he/she produces. On the contrary, the less independent an auditor, the less likely for him/her to produce a high quality audit since the auditor is less likely to be serious in finding and identifying material errors/frauds. Even if the frauds are found, it is highly likely that the auditor will not report them. Patrick, Zayol, Kukeng Vitalis (2017) reviewed some literatures related to 
the relationship between independence and audit quality. Their review results revealed that auditor's independence was one of the important determinants which influenced audit quality. This review was made in Nigeria, particularly in banking sector. The research also suggested further investigation on the relationship between auditor's independence and audit quality beyond Nigeria. This research finding is supported by the research conducted by Zamzami, Tantri, \& Timur (2018) who found that auditor's independence positively influences audit quality. From the explanation above, it is hypothesized as follows:

\section{$\mathrm{H}_{2}$ : Auditor's independence positively influences audit quality}

\section{Influence of Audit Rotation on Audit Quality with Independence as an Intervening Variable}

Auditor rotation also has some influence on audit quality through independence. This is supported by Tobi et al., (2016) who had successfully proved empirically that auditor rotation had positive significant influence on audit quality through independence. This means if KAP rotates their auditors, it is more likely for an auditor's independence to be maintained, hence the auditor would perform well during the audit process and, eventually, the audit quality would be high. According to attribution theory, auditor rotation can be classified as an external factor which might influence an auditor's behavior since auditor rotation is set forth in regularions which require every company to rotate their auditors not longer than 5 years in a row. In this case, auditor rotation as an external factor will indirectly influence an auditor's behavior in producing high quality audit.

Coyle (2010) provided empirical evidence that audit rotation is a way to improve an auditor's independence. Unlike Coyle (2010) and Tobi et al., (2016), Velte \& Stiglbauer, (2012) found no correlation between audit quality and auditor rotation. This research result shows that an auditor's independence improvement cannot be obtained solely by rotating auditors. In line with Velte \& Stiglbauer (2012), Lopo \& Aldecir, (2014) did not found the correlation between audit rotation and audit quality either in Brazil. Therefore, it can be hypothesized as follows:

$\mathrm{H}_{3}$ : Auditor rotation positively influences audit quality with independence as an intervening variable

\section{METHODS}

This research uses quantitative approach and is classified as explanatory research, i.e. research which tries to explain the causal relationship between research variables through hypothesis testing. The data used in this research are primary and secondary data. The secondary data are obtained from the website of PPPK of Ministry of Finance on May 2016, previously known as PPAJP to obtain data on the number of KAPs throughout Indonesia and the primary data are those obtained directly from the subjects, i.e. auditors. The sample used is 90 auditors in Indonesia. The data are collected using questionnaire and interview and the analysis using path analysis.

\section{RESULTS}

The first hypothesis proposed in this research is that auditor rotation (X1) positively influences auditor's independence (Y1). Based on the table, it can be seen that the tatistic value at 0.905 with significance of 0.368 is greater than the $p$ value 0.05 , thus Ho is accepted, meaning that the path coefficient is insignificant. The result of data analysis can be seen in the following table:

Table 1. Regression Results

\begin{tabular}{llll}
\hline Variable & Sig & t statistic & Decision \\
\hline Auditor rotation & 0,368 & 0,905 & $\mathrm{H}_{0}$ accepted \\
Auditor independence & 0,000 & 6,465 & $\mathrm{H}_{0}$ rejected \\
\hline
\end{tabular}


The second hypothesis proposed in this research is that there is a positive influence of auditor's independence on audit quality. Based on the table, it can be seen that the $t$ statistic value of 6.465 with significance of 0.000 is less than $p$ value 0.05 , hence Ho is rejected, meaning the path coefficient is significant. Therefore, it can be concluded that auditor's independence positively influences audit quality.

The third hypothesis proposed in this research is that there is positive influence of auditor rotation on audit quality with auditor's independence as an intervening variable. Based on table 2, it can be seen that there is no direct influence of auditor rotation on auditor's independence as indicated by a significance of 0.368 , which is greater than $p$ value 0.05 at a standardize coefficient (Beta) value of 0.096 and there is a direct influence of auditor's independence on audit quality at a significance of 0.000 and the Beta value of 0.567 , thus the total influence of audit rotation on audit quality through auditor's independence is 0.005 (0.096 x 0.55). Therefore, it can be concluded that there is no indirect influence of audit rotation on audit quality through auditor's independence. The result can be seen in the following table.

Table 2. Path coefficient, direct influence, indirect influence and total influence

\begin{tabular}{lcccc}
\hline \multicolumn{1}{c}{ Influence Variable } & Path Coefficient & $\begin{array}{c}\text { Direct } \\
\text { Influence }\end{array}$ & Indirect & Total \\
\hline $\mathbf{X}$ on $\mathbf{Y}$ & 0.096 & 0.096 & & 0.096 \\
$\mathbf{Y}$ on $\mathbf{Z}$ & 0.567 & 0.567 & & 0.567 \\
$\mathbf{X}$ on $\mathbf{Z}$ through $\mathbf{Y}$ & 0.096 & 0.567 & 0.055 & 0.005 \\
\hline
\end{tabular}

\section{DISCUSSION}

\section{Influence of Auditor Rotation on Auditor's Independence}

The research result indicates that the auditor rotation variable has no influence on auditor's independence. From this finding, it can be interpreted that auditor's independence is not influenced by the presence or absence of rotation. This means that auditor will still maintain their independence even if there is no any rotation. Mautz \& Sharaf (1962) suggested that the lengthy relationship between an auditor and his/her client would influence his/her independence since his/her objectivity would decrease as time went.

Basically, the auditor rotation made KAPs is expected to improve auditor's independence since it helps reduce behavioral threats which may decrease their independence which may eventually lower the audit quality. However, on the other hand, from the interviews with several auditors, it is revealed that it is highly likely for an auditor to miss something (audit evidence) in their first year of performing an audit. For this reason, they think there is no need for a compulsory rotation. Auditors are demanded to understand the client business thoroughly before performing the audit and this cannot be done by an auditor only at the beginning they doing the audit thus a new auditor has no adequate knowledge on the client's business operation, resulting in the auditor failing to detect material misstatement in the financial statements due to lack of information. In addition, new assignment will increase costs and thus increases the overal audit costs and rotation poses risk of audit below the standards for the auditor has not really known their clients.

The overal data analysis shows that most auditors who serve as the respondents had never been rotated when doing the audit at 52 auditors or $57.78 \%$. It is possibly because the respondents in this research are mostly junior auditors working for less than 2 years, hence they have never been rotated. This research result is in line with the studies conducted by Tobi et al., (2016) and Velte \& Stiglbauer, (2012) who failed to find the relationship between auditor rotation and independence and audit quality. This research result shows that an auditor's independence cannot be improved only by rotating them. Also confirming Velte \& Stiglbauer (2012) research, Lopo \& Aldecir (2014) also failed to find the relationship between audit rotation and audit quality in Brazil. Furthermore, Mansi, Maxwell, \& Miller (2004) suggested that investors at capital markets expected surprisingly preferred auditors with longer experience 
and learning with a company considering that the risk encountered by the company also increases, hence the longer relationship between auditors and client is more preferred by the investor for finding material misstatement without unnecessarily concerning any lowered independence.

The research result does not support the research conducted by Chi (2011) who found that the auditor rotation used to mitigate the impact of audit tenure could improve the audit quality and Coyle (2010) who studied 20 KAPs and performed interviews with the regulators found that audit rotation was a way of imrpoving auditor's independence and Mohamed \& Habib (2013) on the need for rotation to improve auditor's independence. This research result also contradicts the research conducted Dattin (2017) in France who douns that the auditor rotation obligation could improve auditor's independence yet insignificantly influenced the audit quality.

\section{Direct Influence of Auditor's Independence on Audit Quality}

The fifth hypothesis which states that there is a positive influence of auditor's independence on audit quality is accepted. This can be interpreted that the higher the auditor's independence the higher the quality of audit produced. The respondent answers on the independence variable shows a very high value at $46.9 \%$, meaning that respondents perceive themselves independent. This independence is shown in three dimensions, namely firstly, programing independence i.e. independence from control or influence in choosing the audit techniques and procedures and the their development in their application. This means that the auditor is free to decide on their own programs, both the steps and the amount of jobs to be performed. The second dimension is investigative independence, i.e. the independence in determining the area, activity, personal relationship, and managerial policies to be tested. The third dimension is reporting independence, i.e. the independence in giving statement of fact generated from the testing or recommendation or opinion as the final outcome of the audit process

When an auditor has high independence as reflected in those three dimensions, the quality of audit will also be high. Currently, an auditor is demanded to be capable of winning back the public trust considering the great number of cases which involve auditors and thus question their independence.

This research result supports the result of research conducted by Patrick, Zayol, Kukeng Vitalis,(2017) who reviewed some literatures related to the relationship between independence and audit quality. Their review results revealed that auditor's independence is one of the important determinants which influenced audit quality. This review was made in Nigeria, particularly in banking sector. The research also suggested further investigation on the relationship between auditor's independence and audit quality beyond Nigeria. This research finding is supported by the research conducted by Zamzami et al. (2018) who found that auditor's independence positively influences audit quality. Audit quality would improve if the auditor performing the audit had high independence.

\section{Indirect Influence of Auditor Rotation on Audit Quality with Auditor's Independence as an Intervening Variable}

The third hypothesis proposed in this research which states that there is a positive influence of auditor rotation on audit quality with auditor's independence as an intervening variable is rejected. The research result shows that auditor's independence is proven not mediating the relationship between auditor rotation and audit quality. This means audit quality is not influenced by rotation which aims to improve auditor's independence.

Many previous studies argued that the audit quality and auditor's competence will decrease as the time goes since the auditor has built a closeness/special relationship with the client and, as a consequence, they will lose their professional scepticism. However, the interview reveals that rotation does not necessarily have impact on audit quality since audit failure is more likely with auditor rotation. The reasons is that replacing the old with the new auditors will take some time and costs higher to grasp what the client business is. In addition, the minimum knowledge of newly appointed auditor on the client business also lower his/her meticulosity and punctiliousness in detecting material misstatements in the 
financial statements and thus will affect the quality of audit he/she produces and the opinion he/she issues.

The research result does not support Castellani (2008) research who stated that the very existence of auditor rotation will improve the auditor's independence and eventually the audit quality will improve. However, the research result is in line with the research conducted by Tobi et al. (2016), Velte \& Stiglbauer (2012) who failed to find the relationship between auditor rotation and independence and audit quality. This research result showed that an auditor's independence improvement could not be obtained only by rotating auditors. In line with (Velte \& Stiglbauer, 2012) research, (Velte \& Stiglbauer, 2012) also failed to find the relationship between audit rotation and audit quality in Brazil.

\section{CONCLUSION}

This research tests the influence of auditor rotation on audit quality with auditor's independence as an intervening variable. Based on the research result, it can be concluded that audit quality is influenced only by auditor's independence, and auditor rotation has no influence on the auditor's independence and, furthermore, it does not influence the quality of audit produced. This indicates that basically auditors are independent and demanded to remain independent in every assignment, free from any influence of closeness with clients (which is attempted to be mitigated using auditor rotation) so that they will produce high-quality audit report.

\section{REFERENCES}

Arens, A. A., \& Loebbecke, J. K. (2003). Auditing: Pendekatan Terpadu (A. A. Jusuf, Ed.). Jakarta: Salemba Empat.

Castellani, J. (2008). Kompetensi dan Independensi Auditor Pengaruhnya pada Kualitas Audit. Trikonomika, 7(2), 114-121.

Chi, W. (2011). The Effect of the Enron-Andersen Affair on Audit Pricing. SSRN Electronic Journal, (886). https://doi.org/10.2139/ssrn.614884

Copley, P. A., \& Doucet, M. S. (1993). Audit Tenure, Fixed Fee Contracts, and the Suplly of Substandard Single Audits (pp. 23-35). pp. 23-35. https://doi.org/https://doi.org/10.1111/1540-5850.00980

Coyle, D. (2010). Audit firm rotation - Its impact on auditor independence: An Irish perspective. Accounting, Letterkenny Institute of Technology, (August), 1-78.

Daniels, B. W., \& Booker, Q. (2011). The effects of audit firm rotation on perceived auditor independence and audit quality. Research in Accounting Regulation, 23(1), 78-82. https://doi.org/10.1016/j.racreg.2011.03.008

Dattin, C. F. (2017). Developments in France regarding the mandatory rotation of auditors: Do they enhance auditors' independence? Accounting History, 22(1), 44-66. https://doi.org/10.1177/1032373216674968

DeAngelo, L. E. (1981). Auditor size and audit fees. Journal of Accounting and Economics, 3(May), 183-199.

Hartono, J. (2004). Metodologi Penelitian Bisnis: Salah Kaprah dan Pengalaman- Pengalaman. Retrieved from http://biblioteca.usac.edu.gt/tesis/08/08_2469_C.pdf

Heider, F. (1958). The Psychology of Interpersonal Relations. New York: John Wiley \& Sons.

IAASB. (2017). Handbook of International Quality Control, Auditing, Review, Other Assurance, and Related Services Pronouncements. Fifth Avenue, New York: IFAC.

Jensen, M. C., \& Meckling, W. H. (1976). Theory of the firm: managerial behavioragency and ownership 
structure. Journal of Financial Economics, 3, 305-360. https://doi.org/10.1016/0304405X(76)90026-X

Lindberg, D. L., \& Seifert, D. L. (2011). A Comparison of U.S. Auditing Standards with International Standards on Auditing. The CPA Journal, 81(4), 17-21. Retrieved from https://search.proquest.com/docview/862636015?accountid=28391

Lopo, M. A., \& Aldecir, B. (2014). Rotation of independent auditors and analysis of their reports before and after rotation in Brazil. Journal of Accounting and Taxation, 6(1), 19-29. https://doi.org/10.5897/jat2013.0128

Lubis, A. (2010). Pengaruh Independensi Pemeriksa, Standar Pelaporan, Pendidikan Berkelanjutan dan Keahlian Auditor Inspektorat Provinsi Terhadap Kualitas Audit. Jurnal Keuangan Dan Bisnis, 2(2).

Mansi, S. A., Maxwell, W. F., \& Miller, D. P. (2004). Does auditor quality and tenure matter to investors? Evidence from the bond market. Journal of Accounting Research, 42(4), 755-793.

Mautz, R. K., \& Sharaf, H. A. (1962). The Philosophy of Auditing. American Accounting Association, 37(3), 599-600.

Mohamed, D. M., \& Habib, M. H. (2013). Auditor independence, audit quality and the mandatory auditor rotation in Egypt. In Education, Business and Society: Contemporary Middle Eastern Issues (Vol. 6). https://doi.org/10.1108/EBS-07-2012-0035

Onwuchekwa, J. C., Erah, D. O., \& Izedonmi, F. (2012). Mandatory Audit Rotation and Audit Quality: Survey of Southern Nigeria. Research Journal of Finance and Accounting, 3(8), 70-77. Retrieved from https://s3.amazonaws.com/academia.edu.documents/29440168/MANDATORY_AUDIT_ROTATI ON_AND_AUDIT_QUALITY.pdf?AWSAccessKeyId=AKIAIWOWYYGZ2Y53UL3A\&Expires= 1506430948\&Signature $=$ LBMxEc\%2BhtXqYFl7w7aA3TrxJNoo\%3D\&response-contentdisposition=inline\%3B filename\%3DIIS

Patrick, Zayol, Kukeng Vitalis, and I. M. (2017). Effect of Auditor Independence on Audit Quality: A Review of Literature. Nternational Journal of Business and Management Invention, 6(3), 51-59.

Purnamasari, S. V. (2006). Sifat Machiavellian dan Pertimbangan Etis : Anteseden Independensi dan Perilaku Etis Auditor. 0812256908, 23-26.

Robert Knechel, W., Krishnan, G. V., Pevzner, M., Shefchik, L. B., \& Velury, U. K. (2013). Audit quality: Insights from the academic literature. AUDITING: A Journal of Practice \& Theory, 32(SUPPL.1), 385-421. https://doi.org/10.2308/ajpt-50350

Tobi, B. A., Osasrere, A. O., \& Emmanue, U. (2016). Auditor' s Independence and Audit Quality: A Study of Selected Deposit Money Banks in Nigeria. International Journal of Finance and Accounting, 5(1), 13-21. https://doi.org/10.5923/j.ijfa.20160501.02

Velte, P., \& Stiglbauer, M. (2012). Impact of Auditor and Audit Firm Rotation on Accounting and Audit Quality: a Critical Analysis of the Ec Regulation Draft. Journal of Governance and Regulation, 1(3), 1-8. https://doi.org/10.22495/jgr_v1_i3_p1

Watkins, A. L., Hillison, W., \& Morecroft, S. E. (2004). Audit Quality: A Synthesis Of Theory And Empirical Evidence. Journal of Accounting Literature, 23(4), 19-153.

Watts, R. L., \& Zimmerman, J. L. (1990). Positive Accounting Theory: A Ten Year Perspective. The Accounting Review, 65(1), 131-156.

Zamzami, F., Tantri, S. N., \& Timur, R. P. (2018). Effects of Auditor Independence and Experience, Size of Client's Financial Health and Audit Fee on Audit Quality: An Empirical Study on Public Accounting Firms in Indonesia. Journal of Economics, Business and Management, 5(1), 69-73. https://doi.org/10.18178/joebm.2017.5.1.488. 